\title{
Technological Non-Co-operation: Britain and Airbus, 1965-1969
}

\author{
Frances $L Y N C H$ \\ Lewis JOHNMAN
}

Anglo-French co-operation to build the world's first civilian supersonic aircraft, Concorde, was a rare example of the British and French governments working together to challenge American hegemony in a field of advanced technology. ${ }^{1}$ Although the British Labour government, foreseeing the commercial disaster which Concorde was to prove, seriously considered withdrawing from its supersonic treaty obligation on several occasions in the 1960s it was as committed as its Conservative predecessor which had signed the supersonic treaty, to co-operating with France in the joint production of aircraft. Indeed in February 1965 it proposed to France that the two governments should sponsor the production of a new wide-bodied aircraft soon to be called Airbus, designed to cater for the rapid expansion of air travel in the 1970s and beyond. This was to form part of the European Technological Community which the Labour Prime minister, Harold Wilson hoped would accompany Britain's entry into the European Economic Community. Although Britain had the technological capability of building on its own both the aero-engines and the airframe for such an aircraft it needed access to the finance and markets which co-operation with France and other European countries could offer. That the future survival of the British aircraft industry depended on its co-operating with its European partners in commercially sound ventures was recognised by the Plowden Commission which had been set up by the Labour government to advise it on its policy towards the aircraft industry. ${ }^{2}$

The situation in France and West Germany, Britain's prospective partners in Airbus, was different. While France had an increasingly successful airframe construction industry, and shared Britain's interest in co-operating for commercial and financial reasons, due to the technological backwardness of its aero-engine industry, it relied on importing aero-engines from the United States. West Germany relied wholly on importing American aircraft under the offset programme. One fear of the British government was that both France and West Germany would continue to import aero-engines from the United States rather than act as junior partners in making them with Britain and could even be seduced by American firms into co-operating with them rather than with Britain, to build airframes. As a result the British hopes of achieving the functional integration of the European aircraft industry and of British membership of the EEC would not be achieved. The American Administration, whilst a long-standing advocate of British membership of the EEC did not support the British government's ambition to create a European

1. We are grateful to David Edgerton for helpful comments on an early revision of this paper.

2. Cmnd. [Command papers] 2853. Report of the Committee of Inquiry into the Aircraft Industry appointed by the minister of Aviation under the chairmanship of Lord Plowden, 1964-1965. 
aircraft industry. The American aircraft corporations were equally opposed. The purpose of this article is to explain why the British government took the decision to withdraw from Airbus leaving the French company Sud Aviation, in partnership with the West German conglomerate, Airbus AG to build the first Airbus. In view of the subsequent success of the Airbus fleet in challenging Boeing's monopoly position in world markets, the British government's decision of 1969 has been described in retrospect as 'without doubt one of the stupidest industrial policy decisions ever made by a British government' ${ }^{3}$ In the mid 1960s France accounted for just 3.7 per cent of the non-communist world's aerospace output in comparison with 7.4 per cent for Britain and 82 per cent for the United States. ${ }^{4}$ Today the Airbus site in Toulouse is the largest aeronautical complex in Europe.

It was Roy Jenkins who, as minister of Aviation in the first Wilson government, proposed in February 1965 to his opposite number in Paris, Marc Jacquet, that the two governments should co-operate to build a wide-bodied aircraft to cater for the rapidly-growing demand for air travel in Europe. ${ }^{5}$ The proposal to the French, made within weeks of the Labour government's failure to cancel Concorde, was one of several such co-operative ventures in aircraft production, the rest being in the military sector. Pre-empting the conclusions of the Plowden Committee, co-operation with France and other European countries was seen as the only way to ensure the survival of the British and European aircraft industry in a world dominated by the USA. But co-operation with France on aircraft production had an even greater significance. Since January 1963 when Charles de Gaulle had vetoed Britain's first application to join the European Economic Community it was understood in London that France remained the obstacle to British entry into the EEC. Any action which improved relations between Britain and France was seen to offer some hope of overcoming de Gaulle's hostility to British membership. Technological expertise was one area in which Britain had, or more importantly was seen to have, something positive to offer to France and the rest of the European Community. This was particularly important in view of the concern increasingly being felt in Europe at the time about a growing technological gap with the United States. ${ }^{6}$ For Prime minister Wilson technology was not only the force which would revive the British economy but it was also a possible passport for British entry into the EEC. ${ }^{7}$

3. Association pour l'étude des problèmes sociologiques, économiques et stratégiques liés aux techniques nouvelles, Evolution de la compétitivité de l'industrie aéronautique française. Comparaison-internationale et intersectorielle: 1970-1980, Paris, 1983, p.171.

4. M. LYNN, Birds of Prey. The War Between Boeing and Airbus, Heinemann, London, 1995, p.115.

5. National Archives, London, (hereafter referred to as N.A.) FV 2/234. Note of an Anglo French ministerial meeting held in London on 16 February 1965.

6. This was to be popularised in the best-selling book by J.-J. SERVAN-SCHREIBER, Le défi amércain, Denoël, Paris, 1967.

7. J.W. YOUNG, Technological Co-operation in Wilson's Strategy for EEC Entry, in: O.J. DADDOW (ed.) Harold Wilson and European Integration. Britain's Second Application to Join the EEC, Frank Cass, London, 2003. 
It was for this reason that he broached the subject of aircraft co-operation with de Gaulle when he visited Paris in April 1965 - the first such visit by a British Prime minister since de Gaulle's veto of 1963. Playing on de Gaulle's fears of an American domination of Europe he explained the British offer to collaborate on aircraft production in terms of the need to reduce British dependence on the United States. ${ }^{8}$ The offer was welcomed. Committees were set up to draft the specifications for a wide-bodied aircraft capable of carrying large numbers of people over short distances - soon to be called Airbus. By December 1965 agreement had been reached to construct an aircraft with between 200 and 225 seats powered by two engines and ready for service by 1974 . This in itself was a compromise between the French wish for a larger aircraft based on their predictions for the expansion of air travel and the more conservative British estimates. Indeed one British official suggested that when the Channel Tunnel was completed air travel would decline significantly. ${ }^{9}$ Where no agreement was reached was on the choice of engine supplier. Indeed the failure of the French to endorse Rolls-Royce from the outset was to be one of the reasons for the British government's subsequent decision to withdraw from Airbus. At that time the engines for Concorde were being designed and built by the French corporation, the Société Nationale d'Etude et de Construction de Moteurs d'Avions, (SNECMA), and the American aero-engine firm Pratt \& Whitney which had a non-majority shareholding in SNECMA, and the Bristol-based Bristol Siddeley engines. The condition for Pratt \& Whitney's participation in SNECMA was that the French firm could not co-operate with Rolls-Royce. To break that condition would have caused SNECMA to lose lucrative American defence contracts. The Macmillan government, in its haste to sign the Concorde Treaty, had little choice but to agree to give the contract for the engines to Bristol Siddeley and SNECMA rather than to Rolls-Royce. ${ }^{10}$ British officials were now not so ready to overlook the interests of Rolls-Royce. Unhappy with the French suggestion to adopt for Airbus whichever engine Boeing was to choose for its new large-scale carrier the Jumbo-jet B 747, designed to carry a pay load of up to 500 passengers, they insisted that studies should be undertaken into the relative merits of the Rolls-Royce RB 178 and the Pratt \& Whitney JT9D engine, regardless of Boeing's decision. ${ }^{11}$

Nonetheless Rolls-Royce's chances of selection received a blow when Boeing announced that it had chosen the Pratt \& Whitney JT9D engine for its B 747. As far as the French were concerned this tipped the scales strongly in favour of selecting the same American engine for a twin-powered Airbus. As they saw it the JT9D engine would have the advantage of two years service on the B 747 which was

8. N.A. PREM 13/324. Visit of the Prime minister and the Foreign secretary to Paris, 2-3 April 1965.

9. Archives Nationales, Paris (hereafter referred to as A.N.) Ministère des Travaux Publics et des Transports (MTPT) 760 069/91. Report of meeting, 16 October 1965. (Work on the Channel Tunnel did not begin for another 20 years).

10. L. JOHNMAN, F.M.B LYNCH, A Treaty Too Far? Britain, France and Concorde, 1961-1964, in: Twentieth Century British History, 3(2002), pp.253-276.

11. A.N. MTPT 760 069/91. Note of a meeting between Fred Mulley and Edgard Pisani, 7 April 1966. 
scheduled to fly in 1970. SNECMA's share of the cost of manufacturing the JT9D was put at 371 million francs as compared with 649 million francs for the Rolls-Royce engine. The Pratt \& Whitney engine would have greater sales and the French firm SNECMA would derive technological benefits from its participation in the general research and tests for the JT9D engine. ${ }^{12}$

Disappointed that it had lost out to Pratt \& Whitney for the contract to make the engine for the Boeing 747 and outraged that it seemed likely to be squeezed out of the home market as well by the choice of an American engine for the Airbus, Rolls-Royce announced a take-over bid for Bristol-Siddeley in June $1966 .{ }^{13}$ The French reacted to the news with alarm recognising that it placed SNECMA in an even weaker position relative to the British aero-engine industry. Their reaction became a second reason for Britain's withdrawal. The news increased the resolve to strengthen the French airframe construction industry and contributed to the decision, announced at the beginning of September 1966, to select Sud Aviation as the French participant in Airbus. ${ }^{14}$ Since Sud Aviation had also been given the contract for Concorde the French decision to concentrate civilian projects in one firm, in contrast to the British defence-inspired policy of spreading government contracts around, ${ }^{15}$ was to enhance Sud Aviation's chances of assuming a leadership role over the European airframe construction industry. The British government, having given the contract for Concorde to the British Aircraft Corporation (BAC) had, before the French had selected Sud Aviation, decided to offer the airframe company Hawker Siddeley the option to work on Airbus. But with the future of Concorde continuously in doubt and with the cancellation by the government in April 1965 of its other major project, the Tactical, Strike Reconnaissance Aircraft (TSR-2) BAC was left in a potentially vulnerable position. ${ }^{16}$ Its efforts to build a successor to its successful jet, the BAC 1-11, was to provide a further reason for the British decision to withdraw from Airbus.

In June 1966 the two main airframe constructors in the United States, Boeing and Douglas, contacted the French and German airframe constructors to propose making an Atlantic Airbus together. While the French thought the offer should be left in reserve in case the negotiations to build a European Airbus broke down, the Germans greeted the American offer enthusiastically.

The British were understandably suspicious of the American firms' motives in the timing of their offers and saw in the French and German response to them the possibility of an Atlantic Airbus being constructed without the British. This, Sir

12. A.N. MTPT 760 041/121. Programme 'Airbus': Situation créée par le choix du moteur Pratt \& Whitney JT9D pour équiper l'avion Boeing 747, no date.

13. P. PUGH, The Magic of a Name. The Rolls-Royce Story, Part Two: The Power Behind the Jets 1945-1987, Icon Books, Duxford, Cambridge, 2001, pp.96-97.

14. N.A. FO 371/190864. Memorandum from T.J.B George, 5 September 1966.

15. Ph. GUMMETT, Civil and Military Aircraft in the UK, in: History and Technology, 9(1992), pp.203-222.

16. Ch. GARDNER, British Aircraft Corporation. A History, Batsford Ltd., London, 1981, pp.108-119. 
Con O'Neill, an under secretary in the Foreign Office, ruefully concluded, would suit the Treasury and British European Airways (BEA) who

'will cheerfully kill the Airbus and for that matter the British aircraft industry, in the faith that the economy would be the healthier without both of them'. ${ }^{17}$

While waiting for the Americans to flesh out their offers the contractors chosen for Airbus by France, West Germany and Britain were asked to calculate their costs. From the outset the cost of Airbus was a major consideration for the British government. Determined not to repeat the mistakes of Concorde and strengthened by the recommendation of the Plowden Report the government made commercial viability one of the criteria against which its involvement and support for any aircraft was to be judged. Thus when the contractors chosen for Airbus delivered their costings to the governments in autumn 1966 alarm bells began to ring in London. The greatest cause for concern was the fact that the industrialists expected governments to cover the launching costs, subsidise the costs of production and carry any commercial risk. In calculating the degree of commercial risk much depended on estimates of the size of the market, and the size of the plane. The industrialists specified a plane with a seating capacity of between 250 and 270 but which would later be stretched to 300 , to meet a total world market demand of between 460 and 660 aircraft of which over half would be in the United States. ${ }^{18}$ Officials in the British ministry of Aviation did not believe that the break-even number of 300 could be sold, and concluded that Airbus would not be commercially viable. ${ }^{19}$ The Germans, who had been invited to participate in Airbus at the beginning of 1966 and who were even more optimistic about the growth in air travel than the French, urged the French to go ahead without the British.

But, for the British to withdraw from Airbus, within weeks of Wilson's announcement to the House of Commons that it was his government's intention to seek membership of the EEC, was seen as a disastrous course of action by the Foreign Office. Indeed Wilson himself had stressed the link between technology and British membership of the EEC in a widely-reported speech in the Guildhall. ${ }^{20}$ It seemed inconceivable that Britain should choose such a time to announce its withdrawal from Airbus. The concern of the Foreign Office was that it should at least be represented on the Official Committee on Technology when it met to discuss Airbus early in $1967 .{ }^{21}$ To its relief the discussions on that committee focussed on trying to find ways of making the Airbus more viable commercially rather than recommending British withdrawal from it. In recognition of the argument that a British withdrawal from Airbus might affect the French and German attitude to British entry into the Community the ministry of Aviation

17. N.A. FO 371/90862. Memorandum from Sir Con O’Neill, 22 June 1966.

18. N.A. FO 371/190864. Letter from T.T. Lidbury, deputy chairman and managing director of Hawker-Siddeley Aviation Ltd. to Sir Christopher Hartley, ministry of Aviation, 14 October 1966.

19. N.A FO 371/190864. 'Airbus'. Joint report to ministers, December 1966.

20. J.W. YOUNG, op.cit. For text of speech see U. KITZINGER, The Second Try: Labour and the EEC, Pergamon, Oxford, 1968, pp.307-310.

21. N.A. FO 371/190864. Memorandum from T.J.B. George to R.J. Priddle, 29 December 1966. 
suggested that the British government could propose that a smaller Airbus with a maximum of 200 seats could be built. This it could argue would be more viable commercially since it would not compete with any new American aircraft. ${ }^{22}$ But this was rejected by the cabinet committee. Another proposal asking the three national contractors, Sud Aviation, Hawker-Siddeley and the German conglomerate Airbus AG to contribute to the launching and production costs, was also rejected on the grounds that while the French and German companies might make such a financial contribution, the British firm would not. ${ }^{23}$

In the end it was left to Wilson to raise the issue with de Gaulle when he visited Paris on 24-25 January 1967 as part of his tour of European capitals designed to win support for Britain's bid for membership of the EEC. The contradiction between Wilson's enthusiasm for the technological contribution which Britain could make in the EEC and the more detailed debate inside government was stark. ${ }^{24}$ In the event the British need not have worried about this contradiction since de Gaulle made it clear that in his opinion, borne out also by the experience of working together on Concorde, it was not necessary for Britain to be a member of the Community for technological co-operation to take place. ${ }^{25}$ Wilson's hopes of progressing towards membership of the EEC were dashed and Airbus had now, like Concorde, to be seen as merely national co-operation. An important, probably the politically most important reason for it, had been removed. It had to stand or fall on commercial and technological grounds. Was there in these circumstances a strong case for participating in Airbus?

The ministry of Aviation remained convinced that the commercial prospects were too poor for the aircraft to meet the Plowden Report's recommendation. With the ministers responsible for aviation from Britain, France and West Germany due to meet in Bonn on 27 January 1967 to take a decision about Airbus it looked as if Britain might withdraw. Four days before the meeting Sir Denning Pearson, the chairman of Rolls-Royce, met with Sir Solly Zuckerman, the government's chief scientific adviser. The timing of the meeting was not accidental since Rolls-Royce wanted to influence the outcome of the meeting in Bonn. Revealing some of the complexities of the politics of aircraft manufacture Pearson explained to Zuckerman the implications for Rolls-Royce of recent developments in the United States. The Lockheed Corporation, having been told that it was no longer in the running to build the American supersonic plane then under consideration, decided instead to turn its energies to building a medium-range airbus with a seating capacity of 250-300. Boeing, still in the supersonic race, was postponing a decision on an airbus. As Pearson explained Rolls-Royce had decided that it stood a strong

22. N.A. CAB 134/3313 Cabinet Official Committee on Science and Technology. International Appraisal by Officials of industrial proposals for a European Airbus. Note by the ministry of Aviation, 6 January 1967.

23. N.A. CAB 134/3313. Cabinet Official Committee on Science and Technology. Minutes of a meeting of the committee, 11 January 1967.

24. N.A. CAB 164/96. Memorandum from N.M Fenn, 20 January 1967.

25. N.A. CAB 128/42. Conclusions of a cabinet meeting, 26 January 1967. 
chance of being selected as the engine maker for the Lockheed airbus and was anxious that its chances were not undermined by a decision taken in Bonn to select its rival, the Pratt \& Whitney JT9D engine before Lockheed had made its choice. Were Lockheed to select an American engine in preference to a Rolls-Royce one, Zuckerman thought that 'the European airbus would [then] be a waste of resources and commercial nonsense'. If on the other hand Lockheed chose a Rolls-Royce one he then considered that there would be room for Europe to develop a twin-engined Airbus and if Lockheed opted for a similar plane it might offer to co-operate with Europe on it. The conclusion to this reasoning was that Britain should do everything to prevent ministers at Bonn from selecting Pratt \& Whitney engines for Airbus. $^{26}$

John Stonehouse, who had replaced Fred Mulley as minister of Aviation, duly represented the interests of Rolls-Royce at the tripartite ministerial meeting in Bonn. In the face of French insistence that no further time should be lost before deciding to adopt the Pratt \& Whitney JT9D engine for the Airbus, reserving the Rolls-Royce one for a second generation Airbus - a position which Germany supported - Stonehouse insisted that a decision on the choice of engine should be postponed. Reluctantly it was decided to ask the airlines themselves to state their preference and to meet again in the middle of March to decide on the choice of engine. $^{27}$

Fairly predictably when the airlines were asked to state their preference BEA opted for the Rolls-Royce engine for technological reasons (more modern technology, quieter engine) and for political reasons (it was a 'European' engine). The other four airlines consulted, two French and two German, all preferred the JT9D on the grounds that it would benefit from three years' experience as the engine for the Boeing 747 which both Air France and Lufthansa would use. Air France and Air Inter were concerned about the length of time which it would take to produce the Rolls-Royce RB 207 engine (which had replaced the RB 178) and Air France was not prepared to accept an aircraft equipped with an RB 207 engine if, once its seating capacity was increased to 300 , the running costs were no longer as low as those of the JT9D. ${ }^{28}$

In this situation the British government remained hopelessly divided. On one side were the Treasury and Board of Trade, both opposed to British participation in Airbus. The Treasury considered the Airbus to be motivated more by questions of international prestige and emotional appeals about the future of the European aircraft industry than by sound economic and commercial judgements. The Board of Trade condemned it for not even meeting the immediate needs of BEA. On the other side was the Foreign Office, pointing out that, although British participation in Airbus was not central to Britain's application to join the EEC, were Britain to

26. N.A. CAB 164/96. F.H Allen, 24 January 1967. Note of a meeting in the Cabinet Office, 23 January 1967.

27. A.N. MTPT 760 069/91. Report of meeting in Bonn, 27 January 1967.

28. A.N. MTPT 760 069/91. Airbus: point des discussions internationales, 20 February 1967. 
withdraw from Airbus such action could not but detract from the argument that Britain's entry into the EEC would bring technological benefits. Somewhere in the middle the ministry of Technology under Anthony Wedgwood Benn, tried to dodge the issue by making the adoption of the Rolls-Royce engine a pre-requisite for Britain's participation in Airbus, without facing up to the question of whether Britain should participate in an Airbus if it did have Rolls-Royce engines. The Official Committee on Science and Technology finally gave its conditional support to British participation in Airbus (albeit with dissentions from the Treasury representatives). ${ }^{29}$

This paved the way for the cabinet itself to endorse British participation in the first phase of Airbus, but the decision was evidently dependent on the savings on imports which Airbus promised as well as on the export earnings accruing were Rolls-Royce to be successful in winning the Lockheed contract. Interestingly, ministers were of the opinion that the same engine, the RB 207, was being proposed for both the Airbus and the new Lockheed jet. Ministerial agreement was also conditional on the initial capacity of the Airbus not exceeding 250 seats. ${ }^{30}$

News that an agreement to proceed with a European Airbus seemed likely was not well-received in Washington. Reflecting the view of many American officials the assistant secretary for Industrial affairs in the US department of Transportation intimated to Sir Solly Zuckerman that Britain 'should leave advanced technology to the United States and concentrate (its) efforts on humdrum manufacturing industry'.

Opinions of this kind were bound to prolong the British venture. As Sir Solly Zuckerman said

'it is hard to imagine how they can be so naïve as to think that the United Kingdom and Europe could afford to abandon precisely those fields which are essential for economic growth and not to see the political impossibility of writing off our investment in advanced research and development over the past 20 years'.31

The main concern of the French was to get an assurance that if they agreed to a Rolls-Royce engine Rolls-Royce would then collaborate with SNECMA not only on Airbus but on other projects as well so that SNECMA would not suffer from breaking its contract with Pratt \& Whitney. The French were not prepared to accept that leadership over the airframe should go to Hawker-Siddeley nor that the three governments should study the expansion of the project to include a three-engined lay-out, such as Lockheed was proposing. But these were minor defeats in what

29. These conditions were: that there was an assured market in the three national airlines; that the launching costs did not exceed the present estimate of $£ 130$ million and would be re-examined at an early stage with the aim of securing a significant reduction; that there was an assurance that the target operating costs of 30 per cent below current types and the in-service date of 1972-73 would be achieved; and that the manufacturers would make a proper financial contribution covering normal production costs and some 20 per cent of development costs. N.A. CAB 134/3309. Cabinet Ministerial Meeting on Science and Technology, 22 February 1967.

30. N.A. PREM 13/1939. A. Wedgwood Benn to H. Wilson, 13 April 1967.

31. N.A. PREM 13/1939. Sir Solly Zuckerman to H. Wilson, 16 May 1967. 
was otherwise seen as a very positive outcome as far as the British were concerned especially in view of the fact that on 2 May 1967 the House of Commons had voted massively in favour of the British application to join the EEC (488 in favour, 63 opposed). ${ }^{32}$

Whatever optimism it engendered in London though was soon to be shattered by de Gaulle. In a press conference held on 16 May 1967 he reiterated all his criticisms of Britain's bid for entry into the EEC which he argued, would cause 'nothing but destructive difficulties' ${ }^{33}$ When Wilson met de Gaulle in Versailles on 19 June 1967 he stressed the point that both countries should become independent of American technology. Evidently still hoping to prise open the door to EEC membership he told de Gaulle that

'Britain had the best aero-engines in the world and that if France and Britain combined they could compete effectively with the United States. The airbus they hoped to make was potentially a good example of this in regard both to engines and airframes'. ${ }^{34}$

However when the results of a two-month design study into the Rolls-Royce RB 207 engine seemed to confirm that it was the best engine in a two-engine layout the reaction in Britain was ambivalent. Wedgwood Benn and the ministry of Technology now saw the optimum solution for Rolls-Royce and for Britain as being the adoption of a different engine, the RB 211 which was being offered to Lockheed, in a three-engined rather than a two-engined European Airbus. But they recognised that, were Britain to drop the RB 207 in the hope that the RB 211 would replace it in a three-engined Airbus, the danger was that the resultant delays might scupper the chances of a European Airbus altogether. Other no more welcome consequences of cancelling the RB 207 could be that the French and Germans would switch back to the Pratt \& Whitney engine or that Britain would lose contracts for both the RB 207 and the RB 211 engines. A further complication arose from the fact that French support for the RB 207 engine was based on SNECMA being involved in its manufacture. Were the RB 207 to be abandoned in favour of the RB 211 Wedgwood Benn felt that any involvement of SNECMA in the RB 211 would jeopardise the chances of that engine ever being adopted in America. Another problem, which was recognised belatedly, was that if Britain supplied the engine for Airbus, France would demand leadership over the airframe. ${ }^{35}$

With the three governments due to take a decision on 25 July 1967 on whether or not to embark on the 'Project Definition Stage' of Airbus, the British government had to make a decision one way or another on the RB 207 and on the Airbus. The comments and advice circulating within the Cabinet Ministerial Committee on Science and Technology at that time revealed no small measure of

32. N.A. PREM 13/1939. John Stonehouse to H. Wilson, 12 May 1967.

33. N.A. PREM 13/2646. Sir P. Reilly to Foreign Office, 16 and 17 May 1967.

34. N.A. PREM 13/1731. Record of conversation between Wilson and de Gaulle, 19 June 1967.

35. N.A. CAB 134/3309. Memorandum from A. Wedgwood Benn to the Cabinet Ministerial Committee on Science and Technology, 17 July 1967. 
distrust tinged with bitterness towards the French, due to the fact that technological joint initiatives were not bringing Britain nearer to entry into the EEC. Wedgwood Benn argued that Britain should not enter into any further collaborative agreements with France until it had been accepted as a member state of the EEC. Douglas Jay, president of the Board of Trade and a strong opponent of membership, stressed the importance of SNECMA not obtaining 'technological information which they might exploit on their own account if the Airbus were cancelled'. In summing up the discussion within cabinet Wilson confirmed that the British government was prepared to proceed to the 'Project Definition Stage' of Airbus in the hope that it could persuade the French and Germans to keep open the option of a three-engine design at least until October/November 1967 when the Lockheed decision was expected, and in the hope that Britain could win leadership over the airframe or the formation of a joint company. ${ }^{36}$ The chances of Britain achieving any of these ambitions was slim which could only strengthen the position of those opposed to British participation in Airbus within the cabinet.

The French on the other hand were prepared to commit themselves to the full project on the sole condition that it would be reviewed in the light of unforeseen circumstances. All three governments accepted the conclusions of the Directing Committee of Officials that the RB 207 engine was satisfactory. On the issue of who should assume overall control of the project the Germans pressed for the creation of a joint company to reflect the political initiative behind the project. However while the French accepted this as a long-term objective they argued that if the Airbus was to meet its in service date of 1973 there was insufficient time to set up an official joint company. The British had to concede this point, as did the Germans although for the British the issue was to ensure that they would not always be excluded from the leadership over the airframe simply because they would have leadership over the engines. Nonetheless the French won control for Sud Aviation over the airframe ${ }^{37}$ and in September 1967 the three governments put their signature to a Memorandum of Understanding on Airbus setting out the terms agreed at the July ministerial meeting.

Airbus was scheduled to fly in 1973 but both BEA and Air France needed an aircraft to cover their medium range flights before then. In Spring 1966 BEA had announced that it would need a new interim plane if it was to survive until the arrival of the Airbus. Unlike Air France which could theoretically downgrade its Boeing 707 from long-haul to medium and short-haul routes to cover the period between the end of the Caravelle and the arrival of the Airbus, BEA had no long-haul planes. Furthermore, the British government refused to allow BEA to purchase the American plane best suited for its needs, the Boeing 727-200 with 160 seats. The only wholly British solution was to adopt an existing plane - the VC10 short-haul with 210 seats or a stretched Trident. But so great was the cost of such

36. N.A. CAB 134/3309. Minutes of a meeting of the Cabinet Committee on Science and Technology, 25 July 1967.

37. N.A. CAB 164/96. Memorandum from John Stonehouse, 26 July 1967. 
an adaptation that the British government was anxious to persuade other European countries to buy it too and postpone the arrival of the Airbus. ${ }^{38}$

By the end of June 1966 both the French and German governments had flatly rejected a British plane for the interim period judging that it would be less economical than the Boeing 727-200 and would arrive one year later. Another option considered by the British government was to support BAC in constructing the BAC 2-11, an aircraft with 185 seats powered by two Rolls-Royce RB 211 engines. Once again the government was divided over whether or not to support the BAC 2-11. Those in favour, who included Anthony Crosland, now president of the Board of Trade, argued that the BAC 2-11 would be an all-British aircraft using British engines which would sell well outside Britain particularly following the devaluation of sterling in November 1967. Moreover since the engines which BAC proposed were the same Rolls-Royce RB 211 engines which were being offered to Lockheed for its Tristar, it was argued that were the British government to support the BAC 2-11 this would improve Rolls-Royce's chances of winning the contract to supply Lockheed, thereby breaking into the lucrative but highly protected American market. ${ }^{39}$ The counter argument advanced by Zuckerman was the fear that the French might object to the British government lending its support to an aircraft which could be a potential rival to the Airbus. The French had already objected strongly to the fact that Rolls-Royce was developing the RB 211 engine in the hope of winning the Lockheed contract as well as the RB 207 engine for Airbus. Sud Aviation had even sent a delegation to the Rolls-Royce factory at Derby to check out its capacity for handling two major engine programmes and returned perturbed that a major effort was being made on the engine design for the American aircraft to the detriment of the engine for the European aircraft. ${ }^{40}$ As Zuckerman argued

'it would be disastrous if Rolls-Royce's activities were to irritate the French to the extent that they pull out of the airbus, if at the same time the company proves unsuccessful in the American market. That way we would get the worst of both worlds. $[\ldots]$ At the moment the European horse looks more like a starter'. ${ }^{41}$

Wedgwood Benn was unequivocal in his support for Airbus. As he pointed out the only way that any European country could hope to meet the challenge of American domination was through a policy of co-operating and market sharing. With total demand in the western world for civil aircraft over the ten-year period $1967-1976$ estimated at about $£ 15,000$ million he claimed that

'a properly organised European aircraft industry supported by co-ordinated European purchasing policies could obtain more than a third. The British share could be $£ 2,750$ million'.

38. A.N. MTPT 760071/122. Notes sur l'Airbus, 10 April 1967.

39. N.A. CAB 134/2608. Cabinet Ministerial Committee on the Aircraft Industry. Paper from A. Crosland, 8 December 1967.

40. N.A. PREM 131/1939. Sir S. Zuckerman to H. Wilson, 10 November 1967.

41. N.A. CAB 164/765. Sir S. Zuckerman to H. Wilson, 10 November 1967. 
He went on to contrast this figure with the $£ 1,500$ million which the British aircraft industry on its own could expect to earn on the basis of past performance. He had no doubt that

'the best long-term future for the British aircraft industry and the best sure outlet for Rolls-Royce engines, lies in co-operation with Europe. This in turn will strengthen engine sales' prospects in the USA; Rolls-Royce itself could not expect to survive without a European airframe industry, ${ }^{42}$

Convinced of the logic of the argument and undeterred by de Gaulle's second veto of the British government's application to join the EEC the cabinet committee took the decision to continue to back the Airbus and not to give any financial help to BAC to enable it to develop the BAC 2-11. ${ }^{43}$

However just when British policy seemed confirmed developments across the Atlantic destabilised it once again. At the end of March 1968 Lockheed decided to select the Rolls-Royce RB 211 engine to power its Tristar jet. As soon as the news came through the minister of Aviation, Stonehouse, wrote to the French and Germans assuring them that the RB 211 order would 'in no way result in any lessening of our support for the European Airbus with RB 207 engines'. The two aircraft, the Lockheed long-range jet and the Airbus medium-range jet would be 'complementary and not direct rivals' he insisted, adding that the British government was confident that Rolls-Royce had the capacity to make engines for both. ${ }^{44}$ While the French did not share this confidence what they most objected to was the discovery that the British government had allowed a private airline, Air Holdings Ltd, to place orders for the Tristar. ${ }^{45}$ This they argued would influence the rest of the Commonwealth to buy the Lockheed jet rather than the European Airbus. ${ }^{46}$

A potentially more serious threat to the Airbus came in May 1968 when Boeing announced its intention of building a medium-range airbus with between 200 and 250 seats, designed to compete directly with the European Airbus. ${ }^{47}$ The confidence of the British government in the ability of Airbus to compete with Boeing evaporated instantly. With the deadline for the three European governments to make a definitive commitment to Airbus - 31 July 1968 - fast approaching, panic set in London. Wedgwood Benn suggested that the British government should insist on a four-month extension period to see whether Airbus' costs could be reduced. ${ }^{48}$ Many others in cabinet expressed the hope that Airbus would be a

42. N.A. CAB 134/2608. Cabinet Ministerial Committee on the Aircraft Industry. 'BEA Re-equipment'. Memorandum by A. Wedgwood Benn, 11 December 1967.

43. N.A. CAB 134/2608. Cabinet Ministerial Committee on the Aircraft Industry. Confidential annex, 12 December 1967.

44. A.N. MTPT 76071/122. Letter from J. Stonehouse to J. Chamant, 29 March 1968.

45. Air Holdings Ltd. was in fact a shadow company set up by Rolls-Royce with the help of Lazards and other financial institutions in the City. Its sole purpose was to place orders for the Lockheed Tristar and thereby enable Lockheed to obtain orders from three airlines as required before its launch. N.A. PREM 15/004. Frederick Corfield to E. Heath, 4 December 1970.

46. A.N. MTPT 760071/122. Letter from J. Chamant to J. Stonehouse, 8 April 1968.

47. A.N. MTPT 760071/122. J. Stonehouse to J. Chamant, 5 June 1968.

48. N.A. CAB 134/2609 A. Wedgwood Benn to Cabinet Ministerial Committee on the Aircraft Industry, 24 May 1968. 
casualty of the political crisis engulfing the Fifth Republic at the time. ${ }^{49}$ Better informed observers explained that since the two main French trade unions, the Confédération Générale du Travail and the Force Ouvrière were both publicly backing Airbus a decision to cancel it and cause significant industrial unemployment was unlikely. ${ }^{50}$ Jenkins, who as minister of Aviation had first proposed collaborating on the Airbus with the French, now as chancellor of the Exchequer, wanted Britain to withdraw immediately. ${ }^{51}$ It was Lord Chalfont, the British ambassador to France, who warned of the political damage which would arise if Britain pulled out of Airbus while France and Germany still wanted to go ahead. 'It must' he said,

'postpone for a very long time indeed the moment when European countries will again seriously contemplate engaging in industrial collaboration with us' ${ }^{52}$

Political 'events' in France did have an impact on Airbus although not in the way that ministers had predicted or hoped. When Maurice Couve de Murville replaced Georges Pompidou as Prime minister in July 1968 he immediately appointed Henri Ziegler as chairman of Sud Aviation. ${ }^{53}$ Ziegler, an aeronautical engineer clearly had a better grasp of aircraft manufacture than his predecessor, Maurice Papon, a former police chief later condemned for his actions during Vichy. Ziegler was in favour of Wedgwood Benn's proposal to have a four-month extension period on Airbus. During that time with Sud Aviation in a position of leadership over the airframe for Airbus, he completely changed the design of Airbus arguing that the original one was technical and commercial nonsense. ${ }^{54}$ The new design which was unveiled on 9 December 1968 was for a smaller Airbus, now called the A300B, with a seating capacity of 200-250 seats and powered by two engines. These engines were no longer to be the RB 207 ones but more powerful versions of the RB 211 which Lockheed had demanded for an enlarged Tristar. While Ziegler recognised that to use the RB 211 engine would mean a saving on development costs for Airbus he re-opened the possibility that Airbus might use American engines instead. ${ }^{55}$

Although in many respects the revised Airbus, the A300B, was closer to the specifications which the British had originally proposed, officials remained sceptical about its commercial prospects, and particularly its chances of breaking into the American market. They also challenged the argument put forward by the French and Germans that the redeveloped A300B still fell within the spirit of the

49. N.A. CAB 134/2609. Cabinet Ministerial Meeting on the Aircraft Industry. Minutes of meeting, 30 May 1968.

50. N.A. AVIA 65/2169. Telegramme from B. Ledwidge, Paris Embassy, to Foreign Office, 17 July 1968.

51. R. CROSSMAN, The Diaries of a Cabinet Minister, vol.3, 1968-1970, Book Club Associates, London, 1978, p.152.

52. N.A. AVIA 65/2169. Lord Chalfont to A. Wedgwood Benn, 16 July 1968.

53. I. McINTYRE, Dogfight. The Transatlantic Battle over Airbus, Preager, Westport Connecticut, 1992, pp.22-23.

54. N.A. FCO 46/409. F.C.K. Gallagher to I.L. Crosthwait, 29 November 1968.

55. Financial Times, 11 December 1968. 
Memorandum of Understanding of September 1967 even though it was no longer committed to using Rolls-Royce engines. To give themselves greater negotiating power the British officials on the Airbus directing committee maintained that a new situation did exist outside of the Memorandum of Understanding which meant that all options could be explored. If the engine could be changed so too could the airframe they argued. ${ }^{56}$ One reason for taking this position was that BAC, having failed to win government support for the BAC 2-11 aircraft had begun work on a 240 seat BAC 3-11 aircraft using two RB 211 engines.

Whatever the French and Germans thought, as far as the British were concerned the debate on Airbus had been re-opened. Jenkins, as chancellor of the Exchequer lost no time in making an explicit link between industrial and social policy. On 11 December 1968 he made it clear that if Airbus were cancelled he would remove his earlier objection to the continuation of welfare milk. The following day Wedgwood Benn told the House of Commons that the government was making no commitment to either the Airbus or the BAC 3-11 or to any new proposal (although the ministry of Technology had calculated that with the help of sub-contractors from other European countries the British government's financial support for the BAC 3-11 would be well below the figure envisaged for the Airbus). ${ }^{57}$ Such a reversal of the minister of Technology's earlier policy of support for Airbus infuriated the Foreign Office, who saw the decision facing the British government no longer as simply one of whether or not to collaborate with Europe but whether or not to enter into direct competition with Europe. ${ }^{58}$

On 5 February 1969 the German cabinet took the decision to build the A300B Airbus preferably on a tripartite basis but with France alone if the British refused to join. ${ }^{59}$ The manner in which the Germans had taken their decision and then pressurised the French and the British to make up their minds, greatly irritated Wilson. At a meeting in Bonn with Kurt Kiesinger, the federal chancellor, Wilson expressed his surprise that the Germans had announced their decision to go ahead with the A300B 'apparently before they had assessed the state of the market and the sales prospects of the aircraft'. Explaining that the British government attached importance to European co-operation in aircraft to ensure for Europe a degree of independence from the United States and to avoid a drain of foreign exchange expenditure on aircraft he stressed that 'British governments had made too many expensive errors in aircraft developments [...] to wish to make such a mistake again'. The hastiness of the German decision might, he feared, make it harder for governments now to negotiate suitable terms with industry. Pointing out that the British government's decision not to go ahead with the original Airbus, the A300, in the summer of 1968, against the wishes of the French and Germans, had been vindicated, Wilson now argued that the BAC 3-11 deserved to be considered

56. N.A. FCO 46/410. Cabinet Official Committee on the Aircraft Industry. 'European Airbus'. Note by the ministry of Technology, 18 December 1968.

57. N.A. FCO 46/411. Note by J.R.S. Guinness, 5 February 1969.

58. N.A. FCO 46/410. Note by J.R.S. Guinness, Defence Policy Department, 10 January 1969.

59. N.A. CAB 164/765 A. Wedgwood Benn to H. Wilson, 10 February 1969. 
seriously, 'even if only as a touchstone against which to measure the merits of the A300B'. ${ }^{60}$

The ministry of Technology advocated deferring a British decision on the A300B for six months to give BEA time to complete its assessment of the competing projects and to give BAC and Lockheed time to reach a decision about possible collaboration. ${ }^{61}$ But the lack of realism of such advice was made all too evident when the French cabinet decided to support the Airbus but to defer a decision on financing it for three to four weeks in order to give the Commissariat au Plan time to determine what would need to be sacrificed in order to accommodate it. Forced to make a decision the British cabinet took the ambivalent one on 25 March 1969, that Britain should not participate in the Airbus project, but that the minister of Technology should be free to re-open the decision 'if the terms on which Britain was offered participation were to be changed materially' ${ }^{62}$ On 29 April 1969 Wedgwood Benn wrote to Wilson suggesting that the government should reverse its decision in order to enable Britain 'to stay in the market for this sort of aircraft'. He went on to propose that the government should give launching aid to Hawker-Siddeley to help it with its work on the wings for the Airbus. Furious when he learned of Wedgwood Benn's proposal, Jenkins wrote to Wilson arguing that nothing had changed to make the economics of Britain's participation in the Airbus any more attractive than when the cabinet had decided against it. He was firm that 'because of its poor market prospects it would be quite wrong to risk government money on developing a part of it'. ${ }^{63} \mathrm{He}$ could have added that it was the politics of Britain's participation in Airbus which had changed since two days earlier de Gaulle had resigned as president of the Fifth Republic. With the major obstacle to British membership of the European Community now removed British participation in Airbus was now not so necessary for political reasons.

If the British government refused to finance the construction of the wings for the A300B for which Hawker-Siddeley had already done most of the design work, and with doubts over the technical competence of any other firm to step into the breech, Franz-Josef Strauss, minister of Defence in the West German government decided to arrange financial help for Hawker-Siddeley. Motivated partly by a wish to see Airbus succeed and partly by a wish to defend the aerospace industry in his Bavarian constituency, Strauss offered Hawker-Siddeley a deal whereby West Germany would finance 60 per cent of the development costs of the wing (amounting to $£ 100$ million) in return for which the British company would sign a fixed-price contract to supply the wings for the aircraft. ${ }^{64}$ Hawker-Siddeley had in essence become a sub-contractor with no say in any decisions. ${ }^{65}$ On 29 May 1969 the French and German governments signed an agreement to establish Airbus

60. N.A. PREM 13/2484. Meeting between H. Wilson and K. Kiesinger, in Bonn, 13 February 1969.

61. N.A. FCO 46/411. Note of a meeting in the Ministry of Technology, 11 February 1969.

62. N.A. PREM 13/2107. R. Jenkins to H. Wilson, 13 May 1969.

63. N.A. PREM 13/2107. R. Jenkins to H. Wilson, 13 May 1969.

64. M. LYNN, op.cit., p.115.

65. McINTYRE, op.cit., pp.24-26. 
Industrie. This entered into force on 13 August 1969. Airbus Industrie was known in France as a 'groupement d'intérêt' (GIE) - a commercial partnership rather than a company, it was not obliged to publish accounts, nor to pay tax. It pooled the capital contributed by its members who in turn were not free to produce any aircraft which competed with the Airbus product range. ${ }^{66}$ According to the agreement of 29 May 1969 the two governments were to base their choice of engine for the Airbus on technical, industrial, commercial and financial grounds. At the end of August Sud Aviation and Deutsche Airbus recommended the adoption of the American General Electric engine, rather than a Rolls-Royce or Pratt \& Whitney engine. ${ }^{67}$

On 23 October 1969 the French inter-ministerial committee took the decision to adopt the General Electric engine but stressed that the decision was not to be made public until SNECMA had secured the best possible deal with the American firm. The Germans, who had shown the greatest belief and determination to get the Airbus built, were happy to comply with the French decision. The nightmare scenario envisaged by the new Pompidou presidency was that were the Rolls-Royce engine to be adopted for Airbus it would be Airbus Industrie rather than the British government which would end up paying for it, as well as paying Hawker-Siddeley to make the wings for Airbus. In addition the French government would end up paying for Concorde while the British government relieved of all expenditure on Airbus and Concorde, would develop the BAC 3-11 on its own to compete with the Airbus. ${ }^{68}$

It would be easy but misleading to explain the British government's decision to withdraw from Airbus in 1969 in terms of the failure of Britain's second attempt to join the EEC and to set up a technological community in Europe. The reasons were more complex and involved issues of cost, tensions between the interests of the airframe construction industry and those of aero-engines, attempts by the American firms, Lockheed and Boeing with the backing of the US Administration, to undermine Airbus before it could present a challenge to their own aircraft in the future. Even after de Gaulle had made it clear that British membership of the EEC was not a necessary pre-condition for technological co-operation to take place, the British commitment to Airbus was retained. It was the doubts about the commercial viability of the Airbus particularly when Boeing announced its intention of building a direct competitor with it which caused the British government reluctantly to withdraw. These doubts were reinforced when, under the leadership of Sud Aviation, the design of the Airbus was changed radically in the space of four months. The final straw came when the French and the Germans refused to guarantee, mainly for commercial reasons, that the revised Airbus would be powered by Rolls-Royce rather than American engines. Airbus had failed to secure British membership of the EEC, had failed to provide a secure market for British aero-engines, had failed to give leadership over the airframe to a British firm and finally failed to be a wholly European aircraft able to challenge American hegemony.

66. M. LYNN, op.cit., p.122.

67. N.A. CAB 164/765. Foreign Office to British Embassy in Bonn, 4 September 1969.

68. A.N. Pompidou Papers. AG5(2)52. Note. 'Airbus A300B', 23 October 1969. 